\title{
A NEW INTERPRETIVIST CONCEPTION OF THE RULE OF LAW*
}

\author{
UNA NUEVA CONCEPCIÓN INTERPRETIVISTA \\ DEL ESTADO DE DERECHO
}

\author{
Dimitrios KYRITSIS**
}

\begin{abstract}
Resumen:
Ronald Dworkin sostiene que el contenido del derecho se limita al conjunto de derechos sujetos a ser adjudicados ante los tribunales. Para Dworkin, el valor de la "legalidad", es decir, el valor que sirve el derecho de manera distintiva cuando funciona adecuadamente, es una virtud de las decisiones judiciales. El objetivo de este artículo es criticar el enfoque hacia las cortes de Dworkin, dado que proporciona una concepción empobrecida de lo que es el valor de la "legalidad", argumentaré que la legalidad tiene una dimensión tanto sistemática como adjudicativa. En su dimensión sistemática, exige que el gobierno en su conjunto esté estructurado de tal forma que garantice el ejercicio adecuado del poder público. Por lo tanto, para que un sistema jurídico presente el valor de la legalidad, no es suficiente que los jueces emprendan el uso de la coerción del Estado bajo ciertas condiciones. Además, el ejercicio del poder público tiene que ser acorde con un esquema de separación de poderes con un objetivo de justicia. Así entendidas, no todas las exigencias de la legalidad son sujetas a ser adjudicadas judicialmente. Esta

* Artículo recibido el 16 de octubre de 2014 y aceptado para su publicación el 6 de noviembre de 2014.

** Associate Professor, School of Law, University of Reading. dimitris.kyritsis@ gmail.com. I thank participants in the Workshop on the Legal Philosophy of Ronald Dworkin organized by UNAM and the Supreme Court of Mexico for their helpful comments. I am also grateful to an audience at the 2014 McMaster Conference in Legal Philosophy, where I also presented the argument of this article, and especially to Eric Encarnacion for his written and oral comments. This article elaborates claims that I make in my monograph Shared Authority: Courts and Legislatures in Legal Theory (forthcoming Hart Publishing).
\end{abstract}




\title{
DIMITRIOS KYRITSIS
}

concepción más amplia de la legalidad que sostengo, se basa en una teoría de legitimidad política que difiere de la de Dworkin. La legitimidad no es un asunto al por menor. Una comunidad política también es legítima cuando tiene garantías sólidas para el ejercicio adecuado del poder, y la separación de poderes resulta crucial entre ellas.

\section{Palabras clave:}

Estado de derecho, legalidad, legitimidad, separación de poderes, interpretivismo, Ronald Dworkin.

\begin{abstract}
:
Ronald Dworkin argues that the content of the law is limited to the set of judicially enforceable rights. For him, legality, the value that law distinctively serves when it goes well, is primarily a virtue of judicial decision-making. The purpose of this article is to criticize Dworkin's court-centrism on the ground that it delivers an impoverished conception of legality. Legality has a systemic as well as an adjudicative dimension. In its systemic dimension it requires that government as a whole is structured in a way that guarantees the proper exercise of public power. Accordingly, for a legal system to exhibit the value of legality, it is not sufficient that its judges direct the use of state coercion under certain conditions. Additionally the exercise of public power must accord with a scheme of separation of powers that is geared towards justice. Not all the requirements of legality thus understood are judicially enforceable. This expansive conception of legality is underpinned by a theory of political legitimacy that differs from Dworkin's. Legitimacy is not merely a retail thing. A political community is also legitimate when it has standing guarantees for the proper exercise of power. Separation of powers is crucial among them.
\end{abstract}

\section{Keywords:}

Rule of Law, Legality, Legitimacy, Separation of Powers, Interpretivism, Ronald Dworkin. 
Summary: I. A Court-Centric Conception of Legality. II. Integrity and its Discontents. III. The Systemic Dimension of Legitimacy. IV. Responding to the Positivistic Challenge. V. Conclusion. VI. Bibliography.

\section{A Court-Centric Conception of LEGALity}

Interpretivists hold the view that legal rights and duties, the content of the law, are determined by the principles of political morality that best explain and justify past political decisions. According to Ronald Dworkin's version of interpretivism the role of those moral principles is famously to license the use of state coercion. Dworkin contends that you have legal duty to pay me $£ 50$ if past political decisions furnish a moral warrant for the state to enforce that duty.

On this view, a political community that only uses its coercive force in this limited way adheres to the rule of law. ${ }^{1}$ For Dworkin the value of the rule of law - or legality as Dworkin also refers to it- is the distinctive virtue that law exemplifies when it goes well. Thus, to cast legal practice in its best moral light, as the interpretive method requires, is to interpret it in light of legality. A crucial feature of this value is that it connects our legal rights and duties with past political decisions. This feature sharpens the contrast between rule by law and rule by men, which lies at the heart of our ordinary understanding of the meaning of legality. To rule by law is to rule in accordance with past political decisions. For interpretivists, this happens when our legal rights and duties are determined by the principles of political morality that best explain and justify those past political decisions. Thus, to have our legal rights and duties determined in this way is to be ruled by law.

Now, arguably the use of the coercive force of the state is controlled by courts. As Dworkin puts it in Justice for Hedgehogs, they are the bodies that 'direct the executive power of sheriff or police.' And so it seems natural to conceive of legality as a virtue that applies characteristically to judicial decisions as opposed to other types of

1 Ronald Dworkin, Justice in Robes (Harvard University Press 2006) 169.

2 Ronald Dworkin, Justice for Hedgehogs (Harvard University Press 2011) 406. 
political decision. Indeed, Dworkin maintains that the rights and duties that comprise the content of the law are those that are judicially enforceable on demand.

In this article, I do not dispute the general interpretivist framework. I take issue only with Dworkin's court-centric conception of legality. To do this I look at the relationship between courts and other political branches, notably the legislature. I argue that, when law goes well, this relationship instantiates a value that is critical for upholding the rule of law. Contrary to Dworkin, I maintain that this value relegates judicial enforceability to a secondary role in our thinking about the law. In assuming the soundness of the interpretivist framework, the argument of this article has the character of a family brawl. Still, as I shall indicate in the final section, it provides a way of responding to some persistent objections levelled against interpretivists from their positivist opponents.

\section{INTEGRITY AND ITS DISCONTENTS}

Let me begin by taking a closer look at Dworkin's understanding of judicially enforceable rights and duties and their ground. They are, he claims, a species of political rights and duties. We have other political rights and duties. We have those that are the job of state institutions other than courts to implement. For instance, it may be true that according to the best theory of justice we have a political right to a minimum income. But presumably the demand for a minimum income is properly addressed to, say, the legislature. When the legislature fails to introduce a minimum income, it does not flout legality but another political value, perhaps justice. Of course, once a minimum income has been legislated upon, then it may be that we have a legal right to it, in the sense that we can demand a court to enforce it. But until that happens, the right to a minimum income remains, to use Larry Sager's terminology, judicially under-enforced. ${ }^{3}$

Here is another example: In many parliamentary systems the Head of state is understood to have the power to dissolve and summon Parliament. However, we think that this power is exercised properly

3 Larry Sager, Justice in Plainclothes (Yale University Press 2006). 
only if it satisfies certain conditions. For instance, we think that the Head of State cannot use this power as a means of promoting her partisan agenda by, for instance, doing away with or obstructing a Parliament that is hostile to it. ${ }^{4}$ In such a case, it is natural to think that the Head of State is committing a political wrong, say because she is subverting democracy. But in most legal systems that I am familiar with, we don't think that this duty can be enforced by a court. For Dworkin, this feature of such duties places them outside the law. But many lawyers -including some interpretivists - see in this an embarrassment to the theory. Thus Mark Greenberg takes it to be 'a familiar idea that the President and Congress may have legal duties that the courts should not enforce. ${ }^{5}$

What explains Dworkin's rejection of that familiar idea and his focus on judicially enforceable rights and duties? The thought seems to be that law answers a pressing moral problem that bears on the political legitimacy of the state. This moral problem is distinct from the problems of political and institutional morality to which the other political rights and duties that I mentioned are an appropriate response. For Dworkin, a regime is legitimate when it directs the executive power of sheriff or police in accordance with a unified conception of political justice, because such a regime manifests the virtue of political integrity. Dworkin offers integrity as an elaboration of the concept of legality. Integrity gives more specific content to legality's requirement that our legal rights and duties be sensitive to past political decisions. We ought to look at past political decisions to glean from them the conception of justice that we had committed to in the past so as to continue to act in accordance with it today. In doing so, we are upholding an ideal of equal concern and respect for all citizens. Arguably, integrity thus understood explains why adherence to legality gives a moral warrant for the exercise of state coercion. The thought seems to be that integrity furnishes a crucial benchmark for legitimacy. On this view, a political community that is inspired by this egalitarian ideal shows itself worthy of the allegiance of its citi-

4 On this kind of case see further Jeremy Waldron, 'Are Constitutional Norms Legal Norms?' (2006) 75 Fordham Law Review 1697.

5 Mark Greenberg, 'The Moral Impact Theory of Law' (2014) 123 Yale Law Journal 1288, 1300, n 28.

Núm. 10, enero-diciembre de 2016, pp. 91-109 
DIMITRIOS KYRITSIS

zens, because it extends the same treatment to all of them, without arbitrary distinction.

I said above that for Dworkin a state that complies with legality is legitimate, insofar as it thereby satisfies integrity. Or, put differently, integrity explicates the conditions for the legitimate exercise of state coercion by courts in terms of adherence to legality, that is, past political decisions. However, this way of understanding the upshot of legality comes at a cost. For one thing, courts committed to legality must engage in moral reasoning to identify the right principles that show our political history in its best light and apply them to the case at hand. This feature of Dworkinian interpretivism has given rise to a persistent objection among its critics, an objection pressed recently by Scott Shapiro. ${ }^{6}$ Shapiro says that interpretivism saddles us with an unworkable judicial epistemology. Maybe, he argues, we can accept that when an exceptional case comes before them, judges will be forced to deliberate morally. But why should we think that ordinary judges have the skills and can command the trust to adjudicate morally contentious issues as a matter of course? No wonder, the critics continue, Dworkin has to devise Hercules, an ideal judge equipped with the unlimited time and ability that would be needed to survey the whole of institutional history and articulate the principles that explain and justify it. But Hercules is a fiction. Our judges are not Herculean.

I will revisit this objection once I have set out my alternative to Dworkin's court-centric conception of legality. But first let me discuss a different problem that I think Dworkin's account runs into. This problem has to do with the concept of integrity. One obvious reason to doubt that integrity delivers a court-centric conception of legality is that Dworkin does not think integrity only governs judicial decision-making. In fact, integrity applies to both legislation and adjudication. Of course, it is doubtful that integrity has sway over the legislature in the first place. Democratic politics routinely allows a new majority to enact policies that are animated by a political platform that may be very different from the platform of the previous majority, and it is far from obvious that the new majority is under a

6 Scott Shapiro, Legality (Harvard University Press 2011) 259-330. 
duty to bring its policies under the same scheme of principle as the policies of the previous one. But let's assume for a moment that legislative integrity makes sense. Why then is integrity in adjudication the mark of legality? If interpretivists use the value of integrity to delineate legality and if integrity governs the decisions of both legislators and judges, why shouldn't we count among our legal rights those political rights that are judicially under-enforced (provided that they flow from legislative integrity)? One might say that when the legislature flouts integrity it would be odd to think that it has made a legal mistake, whereas a court decision that violated adjudicative integrity would rightly be quashed on appeal. But, of course that is not an adequate answer. We wanted to know what makes something a legal mistake and we thought integrity was our yardstick. Now it turns out that there must be a different idea at work which distinguishes which aspect of integrity is relevant to legality and which not.

Furthermore, as I said a moment ago, there are some failures of legislative integrity that are left standing, legally speaking, in the sense that they do not count as legal mistakes. For instance, while Parliament at $t 1$ decided to make car manufacturers liable for a certain type of damages, at $t 2$ - perhaps after an election that installed a new majority in Parliament- it decided to exclude the liability of another category of manufacturers for similar damages, despite the fact that legislative integrity condemns this exclusion. Now, if courts have a standing reason to implement legislative decisions, then these failures will end up contaminating adjudicative integrity as well. You may say that at $t 2$ institutional history has changed and as a result of this change adjudicative integrity now requires something different from what it did prior to the second decision. This of course presupposes that there exists an alternative scheme of principle that justifies the difference in treatment between the two types of manufacturer, and one may be excused for doubting that this will always be the case. ${ }^{7}$ That aside, it should be recalled that our task is not solely to come up with a relatively coherent idea of adjudicative integrity,

7 One such sceptic is Jeremy Waldron. See Jeremy Waldron, 'Did Dworkin Ever Answer the Crits?' in Scott Hershovitz (ed), Exploring Law's Empire: The Jurisprudence of Ronald Dworkin (Oxford University Press 2006) 155.

Núm. 10, enero-diciembre de 2016, pp. 91-109 
DIMITRIOS KYRITSIS

but to furnish a morally compelling basis for political legitimacy. However, it is not clear why such a slightly contrived value would fit the bill.

\section{The SyStemic Dimension of Legitimacy}

What has gone wrong? I want to argue that the problem lies in the fact that Dworkin ignores a crucial aspect of the problem of political legitimacy. He seems to think that political legitimacy is a retail thing, a matter of what right you and I can claim in court. But political legitimacy also has a systemic dimension. For a regime to be legitimate, it is not sufficient that it gets it right or reasonably close to right on individual occasions. It is also important that the regime has standing guarantees that the power entrusted state institutions is not abused. Such guarantees are meant to give assurance that state institutions will on the whole tend to act justly. Without such assurances we increase the likelihood and appeal of defection. Such assurances also strengthen our disposition to comply with the law, even when it is not fully just. ${ }^{8}$ Given those assurances, it is not unreasonable for me to believe that things will be different next time round.

Many of these assurances are properly classed under the concept of separation of powers and pertain to the relationship between courts and other state institutions, especially legislatures. We think that part of what it takes for this relationship to go well is that it is structured in accordance with the precepts of separation of powers. My understanding of this concept is slightly idiosyncratic. As I will be using it, separation of powers includes a division of labour requirement and a checks and balances requirement. It tells us that courts and other state institutions ought to work together in a joint institutional effort, in which tasks are assigned to those with the right credentials to carry them out and where state institutions monitor each other's performance.

8 It is one of the main desiderata of theories of legitimacy to explain why legitimacy does not require full justice. See John Rawls, 'Legal Obligation and the Duty of Fair Play', in S Freeman (ed), Collected Papers (Harvard University Press 1999) $117,119 \mathrm{ff}$. 
Separation of powers, as I understand it, is constitutive of legality, at least in great part. First, it preserves legality's link between legal rights and duties and past political decisions. In a joint institutional effort which each participant may decide on a given occasion depends on the past contributions of the other participants. This is particularly clear, of course, in the case of courts and the legislature. We think the courts have a standing reason to heed the acts and decisions of the legislature. And it also preserves the link between legality and legitimacy. As we have seen, the assurances that separation of powers provides matter for legitimacy, perhaps not in a retail sense but in the systemic sense that I have just explained.

However, separation of powers breaks the link between legality and judicial enforceability. Many of the requirements of separation of powers do not need to be judicially enforceable and in some cases it would be counter-productive if they were made judicially enforceable. They duty to dissolve and summon Parliament presumably falls in this category. But it would be a mistake to think that what my proposal does is solely to broaden the extension of legal rights and duties. In this picture, judicial enforcement changes as well. It is now seen also as contributing to the systemic response that separation of powers furnishes to the problem of political legitimacy. Courts are there to do their part in the joint institutional effort, which involves assisting the other participants in the exercise of their role. It may also involve courts taking on a supervisory function.

Practices of constitutional review of legislation may be understood in this way. An interpretivist that fixes on the retail dimension of legitimacy will only see in such practices the court dismissing a part of institutional history that flouts the principles that explain and justify the rest of the system's record and thereby vindicating the rights of citizens that flow from these principles. But, if we take the systemic dimension of legitimacy seriously, we will appreciate that practices of constitutional review also aim to sustain the overall health of the joint institutional effort. They purport to bolster its legitimacy by introducing an element of checks-and-balances. Of course, once we expand our vision to encompass other institutions that participate in this joint effort, we see that courts are merely an option for institutional design with its pros and cons. No wonder then that

Núm. 10, enero-diciembre de 2016, pp. 91-109 


\section{DIMITRIOS KYRITSIS}

some important political rights are not judicially enforceable. It's because courts may not be particularly good at enforcing them. It may also be because they cannot effectively check how well other state institutions fare in protecting them.

In Justice for Hedgehogs Dworkin argues that this way of carving up the content of the law is beholden to a positivist understanding of law, because it supposes that certain standards 'meet the tests of valid law' ${ }^{\prime 9}$ but that 'there are independent reasons why courts should not try to enforce them. ${ }^{10}$ In other words, it assumes that membership in the law is a matter of social fact only, say the social fact that the constitutional text includes a provision that regulates the summoning and dissolution of Parliament. Thus it is philosophically prior to the moral inquiry into the moral justification of the state's coercive power. By contrast, if we reject positivism, 'there seems no sound theoretical basis' ${ }^{11}$ for the view that something is part of the law but not judicially enforceable. That is because either the principles of political morality that govern the institutional division of labour license judicial enforcement of a right, in which case it is legal, or they do not, in which the right is merely political.

The alternative conception that I have been arguing for shows this to be a false dichotomy. It disputes that judicial enforceability is the litmus test of legality. Legality, it contends, starts much earlier than Dworkin would have us think. It does not fix on the on-demand availability of state coercion but at the point where different state institutions including courts are organized into a joint institutional effort undergirded by separation of powers. Thus the theoretical basis for talking about judicially under-enforced legal standards is not a positivist belief in a value-free notion of legal validity but a belief in the importance of the value of separation of powers for maintaining the rule of law. We talk about a legal duty to dissolve and summon Parliament under certain conditions, not simply because the Founding Fathers provided for it in the text of the constitution but

9 Dworkin, Justice for Hedgehogs (n 2) 413.

10 Ibid.

11 Ibid. 
ultimately because it is part of the scheme of principles that regulates the relationship between the main state actors.

By putting separation of powers front and centre in our understanding of legality, we paint a picture of our legal rights and duties that is, as it were, 'decentralized'. What is legally required in a given case - and what may properly be demanded by citizens - will vary between different types of legal officials. Inevitably, each of them will be 'drawing the boundary of the legal in different ways, and sensibly so, given the nature of their offices'. ${ }^{12}$ Scott Hershovitz relies on this observation to attack the view that there is a distinct domain of legal normativity, whose existence we must establish before asking what morally follows from it. Instead, he argues, we should directly tackle the moral inquiry 'how our legal practices impact our moral rights, obligations, privileges, and powers' ${ }^{13}$ Boundary setting is derivative from — and ancillary to - that basic moral inquiry. 'When we have a project in mind', Hershovitz writes, 'we can ask whether it matters how we draw the boundary [of the legal], and how best to draw it if it does'. ${ }^{14}$ In taking issue with Dworkin's way of delineating law's domain and in insisting on a different one, the proposal offered here may be thought to suffer from the metaphysical prejudice Hershovitz wants to debunk. But this would be to misunderstand its thrust. To begin with, my primary aim is still to answer the moral inquiry. More specifically, it is to single out an important dimension of the impact legal practices make on our moral rights and duties, one that has to do with the way state institutions acting on behalf of the political community are organized into a system. This dimension is relevant to the moral impact of legal practices because it partly defines the proper response to the problem of legitimacy. Like Hershovitz, I also readily acknowledge that the boundary of the legal will be drawn differently depending on one's position in the joint institutional effort. But to this I add that some of those boundaries will be more salient and central to our thinking about law, precisely be-

12 Scott Hershovitz, 'The End of Jurisprudence' (2015) 124 Yale Law Journal [forthcoming].

13 Ibid.

14 Ibid. 
cause of their connection to a value, legality, which is essential to a properly functioning system of law. Perhaps, Hershovitz thinks that even the focus on legality betrays that we are under the lingering influence of the same metaphysical prejudice because it supposes that there is a single master value by reference to which we can collect together all the disparate ways in which law impacts on our rights and duties. But, no dubious metaphysics motivates my proposal. To repeat, what drives it is a conception of political legitimacy and an understanding between legitimacy and our legal rights and duties. The inquiry is moral through and through.

Where does this leave integrity? No doubt, some measure of principled consistency will be a feature of a joint institutional effort aiming at justice. ${ }^{15}$ But since my proposal takes a wide scope view of that institutional effort, it removes some of the pressure on courts to bring all institutional action under a unified scheme of principle. If it is the case that regular elections of the legislative body are an important feature of the joint institutional effort aiming at justice, then courts will typically have good reason, a reason based on democracy, to accept compromises of integrity. And since those compromises are licensed by a joint institutional effort governed by separation of powers, they will - to some extent at least- command the allegiance of citizens, given that separation of powers is a crucial ingredient of political legitimacy. In light of this, we do not need to postulate a separate value that is too precarious and elusive to do the moral heavy lifting. We also do not need to commit to the controversial idea that successive legislative majorities are under a duty - one that in real life they routinely flout - to squeeze their policies within the scheme of principle that can be said to underwrite the legislative record.

I am not saying that all compromises of principled consistency will be licensed by democracy. Separation of powers is not a whitewash. State action is legitimate insofar as it is reasonably aimed at justice. So, although the considerations of institutional design that

15 Scott Hershovitz, 'Integrity and Stare Decisis' in Scott Hershovitz (ed), Exploring Law's Empire: The Jurisprudence of Ronald Dworkin (Oxford University Press 2006) 103. 
comprise the ideal of separation of powers and govern the joint institutional effort exert an independent gravitational force on the role of legal officials, they ought to be balanced against considerations pertaining to the content of the rights and duties that are produced by the acts of state institutions. It is the interplay between these two types of moral consideration that determines the content of the law. This interplay will likely allow some morally sub-optimal outcomes, provided perhaps that they are reasonably aimed at justice. Some outcomes, though, will turn out to be beyond the pale, and as a result will have no effect on our legal rights and duties.

\section{Responding to the Positivistic Challenge}

So far, I have outlined my preferred alternative conception of legality and contrasted it to Dworkin's original account. I will now present a couple of ways in which it also helps us respond to Dworkin's critics.

First, this conception with its attendant shift away from judicial enforceability deflects Shapiro's critique against the interpretivist view of judicial reasoning. Remember, for Shapiro interpretivism commits us to thinking of judges as moral philosophers employing complex moral reasoning to reach decisions in law. But, this is arguably hard to square with legal practice, where as a general matter judges lack the necessary philosophical training to perform such a task and anyway lack the moral authority to adjudicate highly divisive questions of political morality; presumably, we trust the political branches to do that. For the sake of the argument, I am going to accept that Shapiro is right to doubt the reasoning skills and moral authority of ordinary judges. ${ }^{16}$ Even so, on the proposal defended here we do not need to accept Shapiro's diagnosis of interpretivism. If it is true that judges are not well equipped to deal with a certain moral question, then separation of powers, especially its division-

16 Of course, even if Shapiro is in principle right, it is a further question how far the point can be pressed. I shall set this question aside as well. See also Jeremy Waldron, 'Judges as Moral Reasoners' (2009) 7 International Journal of Constitutional Law 2. 


\section{DIMITRIOS KYRITSIS}

of-labour requirement, recommends that they be relieved of it. It then channels the task to the institution that has the comparative advantage. Remember, it is the joint institutional effort that must inspire confidence and trust and can therefore legitimately exercise coercive power over us. Judges play a significant part in this effort but it is not a jurisprudentially privileged one.

Practically, this means that judges may be under a moral duty to defer to the judgment of the competent body and perhaps to do so without questioning that judgment. Again, the warrant for this kind of deference is supplied by the considerations of separation of powers that structure the joint institutional effort. Surely, the flipside of the assignment of a certain power to a state institution is a requirement that its fellow-participants in the joint effort respect its exercise of that power. ${ }^{17}$ Deference is plausibly an emanation of that more general requirement. Equipped with the notion of deference, we can chart a map of the epistemic division of labour between state institutions such that (many of) the problems that Shapiro has in mind are addressed.

Interpretivists acknowledge that it is sometimes a good idea for judges and other legal officials determining what the law requires to rely on heuristics that shortcut moral judgment. For instance, Scott Hershovitz argues that 'we often have reasons to be morally obtuse about our moral obligations'. ${ }^{18}$ This moral obtuseness will occasionally make us regard 'ourselves as subject to legal obligations to do things that we could not have a moral obligation to do'. He gives the following example. A common rule of thumb employed by judges and other legal officials in the legal systems that we are familiar with is that they ought to enforce statutes duly enacted by the legislature. Of course, the legislature may on occasion enact morally horrendous statutes which ought not to be enforced. Still, it may be useful not to scrap or refine the rule of thumb and in fact to preserve the belief that the ordinary role of judges and other legal officials is constituted by it. Perhaps, judges and other legal officials should feel

17 For elaboration of this point see D Kyritsis, 'What is Good About Legal Conventionalism' (2008) 14 Legal Theory 135-66.

18 Hershovitz (n 12). 
a certain compunction when deciding whether to dis-apply a duly enacted statute, as this may force them to approach this question with the requisite caution. Perhaps, the rule of thumb, if believed, can generate such a compunction.

Hershovitz is not here advocating deference in the sense defined in the previous paragraphs. He is talking about cases where 'there is a gap between our working theory of the role of a judge and our case-by-case judgment as to what statutes should be enforced'. ${ }^{19}$ This is why he adds that at the end of the day, when our legal officials are faced with a morally repugnant statute, we 'hope that they will recognize that there are occasions for stepping outside their role and declining to enforce' it. ${ }^{20}$ Hershovitz's strategy addresses Shapiro's critique to some extent. Working theories and heuristics, when effective, can reduce the demands made on judges' ability for moral reasoning. However, it has less to say about the problem of trust. To begin with, nothing in Hershovitz's strategy compels legal officials to adopt, follow and believe in working theories. At best, his strategy makes room for such theories in our language and moral thinking. But, God forbid, some legal official might chance upon Law's Empire and become convinced by it to engage in full-blown moral theorizing to decide cases before her. 'Enforce all duly enacted statutes', she will think, is a poor substitute for this kind of theorizing. She will therefore discard the old working theories that kept her day-to-day role epistemically less demanding. But in so doing she will expose herself to the charge that she is betraying or stretching citizens' trust, putting us back at square one. There is a further problem as well: What can we say to bring the philosopher-judge back into the fold? One thing we cannot say is that it is useful to believe that the working theory actually determines the content of her institutional role. In a way reminiscent of rule-utilitarianism's failure, this reason cannot be made public. But it is the only one Hershovitz supplies.

19 Ibid.

20 Ibid. When Hershovitz talks of role here, he obviously means the understanding of the role under the rough and ready working theories whose usefulness he wants to defend, not according to the best moral understanding of one's official role in accordance with the extant scheme of separation of powers. 


\section{DIMITRIOS KYRITSIS}

By contrast, the kind of deference I have been arguing for encompasses cases where it is legally appropriate for a morally sub-optimal decision to stand because those charged with enforcing and implementing it are not authorized to judge aspects of its moral merit. Deference, thus understood, is not vulnerable to the concerns I raised above about the stability of Hershovitz's strategy. It may not block all moral reasoning; judges will still have to answer many moral questions, including those pertaining to the institutional morality of their relationship with the political branches. But it gives them a good reason not to undertake the moral reasoning that has been assigned to another state actor. This may still leave Shapiro unsatisfied, but it should be good enough for most practical purposes. We should definitely be wary of overburdening judges with moral judgments, but there is little reason to insist that they not exercise any moral judgment whatsoever, especially in light of their independence and impartiality. Second, the reason for deference that I have put forward passes the publicity test, because it can be acknowledged by judges without short-circuiting their sense of official responsibility and addressed as a justification to other officials and citizens. Separation of powers is an explicit part of the public effort to make our political regimes legitimate.

More fundamentally, the shift from integrity to separation of powers provides the resources to defend interpretivism from the objection that it is, at best, a theory of adjudication. Many positivists have argued that the interpretive process, as Dworkin understands it, takes as given a set of laws and merely adds a moral gloss on them. ${ }^{21}$ Thus, it must presuppose something like the positivist criteria for determining which items enter the set. As a consequence, it is not really at odds with legal positivism. It occupies an analytically later stage.

Whether or not that is a fair critique of Dworkin's version of interpretivism, it does not sting the version put forward here. For, as I

21 Nicos Stavropoulos distinguishes a number of different versions of this view. See Nicos Stavropoulos, 'Legal Interpretivism' in E Zalta (ed), The Stanford Encyclopedia of Philosophy (Summer 2014 edition), available at <http://plato.stanford. edu/archives/sum2014/entries/law-interpretivist/>, section III. 
mentioned above, I am proposing that the reason why, say, a statute is relevant to what courts must decide is internal to the interpretive project. When it is relevant, it is because and insofar as both courts and the legislature are fellow-participants in a joint institutional effort aiming at justice and structured by the value of separation of powers. In this capacity, they are normally under a duty to heed each other's contributions to the joint effort. This takes the wind out of the sails of any attempt to break up the inquiry about the content of the law into two stages, one value-free stage where certain standards are deemed to be valid law, and another value-laden stage where these standards are combined with moral considerations. If political morality does not give courts sufficient reason to further a legislative decision, there is no residual sense in which that decision has nevertheless created a valid law. The objection takes for granted that legislatures create laws and courts apply them. But on the view defended here both the legislature's power and the courts' duty are determined by principles of political morality that provide part of the answer to the problem of political legitimacy.

\section{CONCLUSION}

Dworkin often spoke about the flexibility our linguistic practices afford us when using the word 'law'. ${ }^{22}$ Sometimes we employ it to refer simply to systems of governance that exercise effective control of a certain territory in the manner of a sociologist or political scientist. We also talk about deeply immoral laws whose enforcement no principle of political morality could deem legitimate such as, notoriously, Nazi law. Dworkin did not regret this flexibility. In fact, he thought that it often helps us capture crucial moral nuances of legal practice. Still, he insisted, the task of the legal philosopher is to articulate legality and explain why legality is central to political

22 See for instance Ronald Dworkin, Law's Empire (Hart Publishing 1998) 103: '[0]ur language and idiom are rich enough to allow a great deal of discrimination and choice in the words we pick to say what we want to say, and our choice will therefore depend on the question we are trying to answer, our audience, and the context in which we speak'. 
legitimacy. This, and not a taxonomic obsession, is the driving force behind the proposal of this article. But it is one that takes legal philosophers away from the all too familiar court setting. Our concern for political legitimacy encompasses the acts of institutions other than courts, and law, as I have tried to show, is integral to addressing that concern. Mind you, law leaves out many aspects of political legitimacy. But this is as it should be. Law is intertwined with morality but is far from ideal. Considerations of political legitimacy can serve both as determinants of the content of the law and as the benchmark against which we evaluate the law, as the aspiration towards which law strives.

\section{BIBLIOGRAPHY}

Dworkin R, Justice in Robes (Harvard University Press 2006).

Dworkin R, Justice for Hedgehogs (Harvard University Press 2011).

Dworkin R, Law's Empire (Hart Publishing 1998).

Greenberg M, 'The Moral Impact Theory of Law' (2014) 123 Yale Law Journal 1288.

Hershovitz S, 'The End of Jurisprudence' (2015) 124 Yale Law Journal.

Hershovitz S (ed), Exploring Law's Empire: The Jurisprudence of Ronald Dworkin (Oxford University Press 2006).

Kyritsis D, 'What is Good About Legal Conventionalism' (2008) 14 Legal Theory 135-66.

Rawls J, 'Legal Obligation and the Duty of Fair Play' in Freeman S (ed), Collected Papers Cambridge (Harvard University Press 1999).

Sager L, Justice in Plainclothes (Yale University Press 2006).

Shapiro S, Legality (Harvard University Press 2011).

Stavropoulos N, 'Legal Interpretivism' in Zalta E (ed), The Stanford Encyclopedia of Philosophy (Summer 2014 Edition). 
Waldron J, 'Are Constitutional Norms Legal Norms?' (2006) 75 Fordham Law Review 1697.

Waldron J, 'Did Dworkin Ever Answer the Crits?' in Hershovitz S (ed), Exploring Law's Empire: The Jurisprudence of Ronald Dworkin (Oxford University Press 2006).

Waldron J, 'Judges as Moral Reasoners' (2009) 7 International Journal of Constitutional Law 2. 